knowledge, and in particular of the art of using it thoughtfully and with set purpose. A difficulty will be to find teachers; men of action and ability are too much in demand for commercial or industrial posts. Teaching, in the main, is missionary service. Prof. Armstrong looks to the universities to break a vicious circle; but at present they are "so steeped in professionalism that they are of little use to the ordinary world ; they neglect general education on behalf of so-called research". We are entirely with Prof. Armstrong in his plea for a wider spread of knowledge, but he will forgive us for reminding him that we cannot both have our cake and eat it unless in some way we provide more cake.

\section{Dr. C. V. Drysdale, C.B., C.B.E.}

THE thirteenth Duddell Medal of the Physical Society was presented on February 7 to Dr. C. V. Drysdale, who is distinguished for his outstanding work in connexion with electrical and optical instruments. Dr. Drysdale was responsible for the design of the first accurate single-phase standard wattmeters in 1901, following them immediately by the first double wattmeters for polyphase measurements, and a few years later by accurate phase-shifting transformers for wattmeter and supply meter testing. In 1909 he adapted the phase-shifting transformer to the design of the first alternating and direct current potentiometer, and devised a vibration galvanometer and low inductance resistance standards which enables that instrument to be used for standardising purposes as well as for general testing, applying it particularly to transmission in telephone circuits. He was also responsible for other electrical standardising apparatus. In 1899, he took charge of the Electrical Engineering and Applied Physics Department of the Northampton Institute, Clerkenwell, and in the following year started the first Technical Optics Department at the Northampton Institute, with a lens grinding workshop. Then came a period of active research in optics, and including the design of lens systems, a universal optical bench for the rapid testing of spherical and cylindrical lens, etc.

Dr. DRYSDale was president of the Optical Society in 1904. In 1915 he entered into partnership with $\mathrm{Mr}$. H. Tinsley for the production of instruments for the War, but at the end of 1917 he was called to the Admiralty Experimental Station at Harwich for antisubmarine research, in the course of which he devised sensitive A.c. relays, a system of 'leader gear' for guiding ships along submarine cables, and various acoustic devices, some of which were described in his Kelvin Lecture to the Institution of Electrical Engineers in 1920. From 1921 until 1929 he was superintendent of the Admiralty Research Laboratory at Teddington. During this time he collaborated with Mr. A. C. Jolley in writing a book on "Electrical Measuring Instruments" ; he also edited the Journal of Scientific Instruments from 1925 until 1928. Dr. Drysdale held the appointment of director of scientific research to the Admiralty from 1929 until 1935, when he retired.

\section{Earth-Tremors in Montserrat}

Fon some time, according to The Times of February 7, earth-tremors have been occurring in Montserrat, one of the Leeward Islands. The subject having been referred to it by the Colonial Secretary, the Royal Society has recommended that an expedition should be sent to the Island to make a careful study of the tremors, and has undertaken to organise it and contribute the sum of $£ 300$ towards the cost. Since its discovery in 1493, Montserrat has shared to some extent in the destructive earthquakes of neighbouring islands, especially in those of Antigua in 1690, 1785, 1831 and 1874, and of Guadeloupe in 1843. In 1897-99, it was, however, visited by four semidestructive earthquakes (intensity I., Milne scale), the origins of which must have been within, or close to, the Island. Whether the recent tremors are the forerunners of another earthquake of the same type or of an eruption of the Soufrière, or merely an isolated series of slight earthquakes, would be determined effectively by the erection of portable tremo. meters, such as are used on similar occasions in Japan, at four stations in different parts of the Island. From the duration of the preliminary tremors, it would be possible to determine the surface position and depth of the focus of every earthquake recorded at all four stations. The results so obtained could not fail to be of value. At the same time, they might tend to allay anxiety in the Island or to suggest precautions for the future.

\section{Palæolithic Types in the American Stone Age}

Ar the St. Louis meeting of the American Associa. tion for the Advancement of Science on December 30January 4, Prof. E. B. Renaud, of the University of Denver, reported the discovery of a large number of stone implements by the Denver University Archæo. logical Survey of the State of Wyoming in the summer of last year. This survey is part of a comprehensive scheme initiated by Prof. Renaud for the inspection and, where feasible, investigation of the archæological sites of Colorado and adjacent States of the south. west, which has now been in progress for some years, and has already achieved some important results. The present find, according to a report circulated by Science Service, Washington, was made in a series of what Prof. Renaud describes as river terraces along the valley of Black's Fork, in south-western Wyoming, and consists of tools, rejects, scraps and pebbles numbering nearly eleven hundred in all. The principal interest of the discovery, however, lies in the fact that Prof. Renaud has classified the imple. ments into five groups, which correspond to the sequence of European palæolithic cultures, Chellean, Acheulean, Mousterian, etc. They are also said to correspond with the stone age implements of the Nile Valley. Prof. Renaud, in stating that this is the first time such a complex of prehistoric stone industry has come to light in North America, regards it as possible that the discovery "may be very significant". In the absence of more precise data and the verdict of geologists and palæontologists, which he awaits, it is not possible to arrive at a critical estimate of 